\title{
NYMPHAYOL AND GERBOLIDE A FROM Artemisia porrecta
}

\author{
S. M. Adekenov, ${ }^{*}$ A. S. Kishkentaeva, N. D. Al'murzin,
}

UDC 547.314

\author{
A. E. Esenbaeva, and G. A. Atazhanova
}

The genus Artemisia L. is one of the largest taxa in the Asteraceae family and is interesting with respect to chemistry because it is the source of many secondary metabolites including terpenoids, flavonoids, and coumarins [1,2]. We studied the aerial part of $A$. porrecta Krasch. ex Poljakov growing in South Kazakhstan Province, Republic of Kazakhstan [3].

The aerial part (leaves, flower heads, buds) of the plant $(0.450 \mathrm{~kg})$ that was collected during flowering in DombraSyrnai gorge in the vicinity of Karatau State Preserve of South Kazakhstan Province was extracted $(3 \times)$ with $\mathrm{CHCl}_{3}$ to afford total extracted substances $(45.0 \mathrm{~g})$. The condensed extract was worked up with aqueous EtOH (1:2). The filtrate was worked up with $\mathrm{CHCl}_{3}(1: 1)$. The resulting total extracted substances $(20.13 \mathrm{~g})$ were chromatographed over a column of KSK silica gel (extract:sorbent ratio 1:25).

Elution of the column by petroleum ether:EtOAc (95:5) isolated colorless crystalline compound $1, \mathrm{mp} 139-141^{\circ} \mathrm{C}$, $\mathrm{C}_{25} \mathrm{H}_{42} \mathrm{O}$. The yield was $0.037 \mathrm{~g}\left(0.009 \%\right.$ calculated for air-dried raw material), $R_{f} 0.47$ (petroleum ether:EtOAc, 4:2).

Based on spectral data (IR, UV, PMR, and ${ }^{13} \mathrm{C}$ NMR), physicochemical constants, and comparison with an authentic sample, 1 was identified as 25,26-dinorcholest-5-en-3 $\beta$-ol, i.e., the steroid nymphayol, which was isolated previously from Nymphaea stallata Willd. [4].

Elution of the column by petroleum ether:EtOAc $(9: 1)$ isolated colorless crystalline compound $2, \mathrm{mp} 168-170^{\circ} \mathrm{C}$. The yield was $0.068 \mathrm{~g}\left(0.015 \%\right.$ calculated for air-dried raw material), $R_{f} 0.31$ (petroleum ether:EtOAc, 2:3).

The mass spectrum of 2 contained a peak for the molecular ion with $m / z 292.2[\mathrm{M}]^{+}$. According to high-resolution mass spectrometry data, 2 had the formula $\mathrm{C}_{17} \mathrm{H}_{24} \mathrm{O}_{4}$.

According to IR, UV, PMR, ${ }^{13} \mathrm{C}$ NMR, and mass spectral data, 2 was the sesquiterpene lactone $9 \beta$-acetoxy$6 \beta, 7 \alpha, 11 \beta(H)$-germacr-1(10),4(5)-dien-12,6-olide (herbolide A), which was isolated previously from $A$. herba-alba subsp. valentine [5].

Thus, the chemical study of the aerial part of $A$. porrecta isolated the steroid nymphayol and the germacrane sesquiterpene lactone herbolide A, which were identified from this species for the first time.

\section{REFERENCES}

1. L. N. Pribytkova and S. M. Adekenov, Flavonoids from Plants of the Genus Artemisia [in Russian], Gylym, Almaty, 1999, p. 180.

2. V. M. Malikov, A. I. Saidkhodzhaev, and Kh. N. Aripov, Chem. Nat. Compd., 34, 202 (1998).

3. Flora of Kazakhstan [in Russian], Vol. 9, Alma-Ata, 1966, p. 639.

4. P. Subash-Babu, S. Ignacimuthu, P. Agastian, and B. Varghese, Bioorg. Med. Chem., 17, 2864 (2009).

5. R. Segal, I. Feuerstein, H. Duddeck, M. Kaiser, and A. Danin, Phytochemistry, 22, 129 (1983).

International Research and Production Center Phytochemistry, 100009, Republic of Kazakhstan, Karaganda, fax: 8 (7212) 4331 27, e-mail: phyto_pio@mail.ru. Translated from Khimiya Prirodnykh Soedinenii, No. 3, May-June, 2013, p. 453. Original article submitted January 11, 2013. 